\title{
THE DETERMINATION OF THE CONCENTRATIONS OF METAMIZOL SODIUM IN INFLAMED JOINTS OF PIGS AFTER INTRAVENOUS AND IONTOPHORETIC APPLICATION
}

\author{
ĐURĐEVIĆ $S^{*}$, JEZDIMIROVIĆ MILANKA**, ALEKSIĆ NEVENKA**, BRANKOVIĆ NATAŠA***, \\ PRŽULJ $\mathrm{D}^{\star \star \star \star}$ and CICOVIĆ $\mathrm{B}^{\star \star \star \star *}$ \\ *Military Medical Academy, Belgrade, Serbia \\ **University of Belgrade, Faculty of Veterinary Medicine, Serbia \\ ***Faculty of Sports and Physical Education Niš, Serbia \\ $\star * * *$ University of Eastern Sarajevo, Faculty of Physical Education and Sport, Republic Srpska, \\ Bosnia and Hercegovina
}

(Received 21st November 2009)

Concentrations of the NSAID metamizol sodium $(\mathrm{MmNa})$ in the synovial fluid and hyaline cartilage of inflamed knee and elbow joints of pigs after i.v. application and iontophoresis (IPh) were investigated. The research was conducted on 14 male pigs divided equally into two experimental groups and exposed to artificial inflammation of knees and elbows prior to the application of $\mathrm{MmNa}$. The first group (A) was administered $2.5 \mathrm{~g}$ (twice the maximum therapeutic dose) $\mathrm{MmNa}$ intravenously, whilst the second group $(B)$ was exposed to the same dose, but applied by IPh into contralateral knee and elbow joints. Four hours after the application of MmNa biopsies of the affected knee and elbow joints were performed. The average concentration of $\mathrm{MmNa}$ in the synovial fluid of inflamed joints in group $A$ was $9.81 \pm 1.96 \mu \mathrm{g} / \mathrm{g}$, while in group $B$ was $170.66 \pm 2.07 \mu \mathrm{g} / \mathrm{g}$, being 17 times higher. The average concentration of $\mathrm{MmNa}$ in the hyaline cartilage was $2.29 \pm 1.16 \mu \mathrm{g} / \mathrm{g}$ following i.v. administration and $98.36 \pm 21.58 \mu \mathrm{g} / \mathrm{g}$ after IPh, i.e. approximatelly 43 times higher. This led to the conclusion that IPh of $\mathrm{MmNa}$, resulting in incomparably higher concentrations in inflamed joints without any adverse systemic effects, has an advantage over i.v. application.

Key words: iontophoresis, knee and elbow joints, metamizol sodium, pig

\section{INTRODUCTION}

Metamizol sodium (dipyrone) is a pyrazolone non-steroidal antiinflammatory drug (NSAID) which has been used for several decades in veterinary practice for therapy of inflammations and disorders of the musculoskeletal system, as well as in the supplemental and/or symptomatic therapy of various bacterial and viral infections. Metamizol has been approved for use in humans, as well as in horses, cattle, pigs and dogs (EMEA, 2003). 
Metamizol sodium administered parenterally exerts several therapeutics effects, namely anti-inflammatory, analgesic and spasmolytic (Fendrich, 2000; Bigal et al., 2001; Boothe, 2001; Laird et al., 2001; Grundman et al., 2006). On the other hand, metamizol sodium produces a series of side effects in the gastrointestinal and urinary systems (Weissmann, 1991).

In certain cases the application of metamizol sodium or some other NSAIDs by topical-iontophoresis in inflammatory joints of animals and people is necessary, thus avoiding systemic adverse effects. This route of application has advantages over i.m. and i.v. applications in some animal species (Asmardi et al., 1985; Tashiro et al., 2000; Lees et al., 2004).

lontophoresis is a safe, painless and highly efficacious mean of drug application locally into the tissue, using galvanic current, which results in a synergistic therapeutic effect of the galvanic current and the drug itself (Ciccone, 1995; Banga and Panus, 1998). The alternative local topical application is phonophoresis, which seems equally efficacious (Baskurt et al., 2003). In spite of its applicability, iontophoresis is feasible only when certain preconditions for its use are met, the main concerning the substance which is to be applied, such as its hydrosolubility, and high degree of electrical dissociation. In addition, lipophilicity affects the electrophoretic delivery of drugs into the skin, as was shown for NSAIDs, whose concentrations in the skin were higher in the case of more lipophilic drugs (Tashiro et al., 2001).

Molecules of low molecular weight (less than 8000 daltons) migrate much faster than those of higher weight (Phipps et al., 1989). For this reason, local anesthetics for instance lidocaine, antibiotics such as gentamicin and ceftiofur, corticosteroids such as dexamethasone and NSAIDS, for example phenylbutazone and flunixin meglumine, are frequently delivered topically, by iontophoresis.

\section{MATERIAL AND METHODS}

Medicines. Novalgetol inj. (Galenika, Belgrade) containing $2.5 \mathrm{~g}$ metamizol sodium per vial (5 mL of solution for injection) was tested.

In addition, azaperone was obtained from Janssen (Stresnil, Janssen Animal Health), and turpentine from Florame, France (Turpentine organic essential oil).

Povidone iodine solution (Povidon jod, Zorka Pharma, Sabac) was used as a disinfectant.

Animals. The research was conducted on 14 eight-week-old male pigs, crossbreeds of the big Yorkshire and Swedish landrace, weighing $24.5 \mathrm{~kg}$ on average and treated in accordance with The European Convention for the Protection of Vertebrate Animals used for Experimental and Other Scientific Purposes. Food and water were given ad libitum (Candek-Potokar et al., 2002).

Experimental protocol. The animals were divided into two groups ( $A$ and $B$ ), each consisting of seven pigs. Half an hour before treatment they were sedated with azaperone in the recommended dose $(2 \mathrm{mg} / \mathrm{kg}$ bw, i.m). Four days prior to the administration of metamizol all the animals were applied $0.2 \mathrm{~mL}$ of turpentine 
intra-articulary into the left elbow joint and contra lateral knee joint (artificial iatrogenic inflammation). The temperature of the inflamed joints was measured by digital cutaneous thermometry. Inflammation was confirmed by histological examination of the joint tissues obtained by biopsy (Vangsness et al., 1997).

All the pigs were administered $2.5 \mathrm{~g}$ metamizol sodium; animals in group A intravenously (jugular vein) and in group B by iontophoretic means. Having in mind that metamizol sodium dissociates on $\mathrm{Na}+$ and metamizol anions, metamizol sodium was applied from the cathode. The cathode was wrapped in four-layer sterile gauze wetted with physiological salt solution (PSS), thus avoiding unpleasant sensations. The electrodes made of rubber carbon fibres were attached and fixed with a rubber bandage on the prepared skin (shaved and disinfected) of the affected knee joints. The dimensions of the anode were $6 \times 8$ $\mathrm{cm}$ and the cathode $7 \times 9 \mathrm{~cm}$. In accordance with the results of previous investigations the intensity of the galvanic electric current was $7.5 \mathrm{~mA}$, the duration $15 \mathrm{~min}$. - totally: $112 \mathrm{~mA}$. In order to shorten the duration of the IPh and to improve the effects of the treatment, infrared rays were applied simultaneously (distance from the skin $50 \mathrm{~cm}$, duration $10 \mathrm{~min}$ ).

Four hours after the drug application the pigs underwent joint punctures of the affected knees. The obtained tissue samples (synovial fluid and hyaline cartilage) were subjected to the determination of the concentration of $\mathrm{MmNa}$ and to histological investigation (Maitland, 1986; Berkow, 1987).

Analytical method. The identification and quantification of $\mathrm{MmNa}$ in the inflamed joints (synovial fluid and hyaline cartilage) were done by fluid-mass spectrometry on the HPCL WATERS 2695 Alliance system, supported with ZQ Mass Detector WATERS - Single quadropo.

Statistical analysis. The data were processed statistically by paired Student's t-test for small samples and regression analysis with correlation (DOS Software).

\section{RESULTS}

In the present research the concentrations of $\mathrm{MmNa}(\mu \mathrm{g} / \mathrm{g})$ were determined in the synovial fluid and hyaline cartilage, which are considered to be the two tissues of utmost importance for physiological functioning of moveable joints.

Four days after the intraarticular application of turpentine oil, i.e. artificially provoked inflammation, in all the animals signs of inflammation in the affected joints were present: heat, redness, swelling and impaired function. The average increase in local temperature was $1.2^{\circ} \mathrm{C}$. The inflammation was proved by histological examination of affected joint tissues performed at the end of study.

Following intravenous administration, the average concentration of $\mathrm{MmNa}$ in the synovial fluid of inflamed elbow and knee joints was $9.81 \pm 1.56 \mu \mathrm{g} / \mathrm{g}$ and in the hyaline cartilage $2.29 \pm 1.16 \mu \mathrm{g} / \mathrm{g}$. On the other hand, the average concentrations of $\mathrm{MmNa}$ after electrophoretical application were the following: in the synovial fluid $170.66 \pm 2.07 \mu \mathrm{g} / \mathrm{g}$ and in the hyaline cartilage $98.36 \pm 21.58 \mu \mathrm{g} / \mathrm{g}$ (Tables 1 and 2). 
The concentration of $\mathrm{MmNa}$ in the synovial fluid obtained from the inflamed joints of pigs in group $\mathrm{B}$ (MmNa administered by IPh) was significantly higher in comparison with the average concentration in group $\mathrm{A}$ ( $\mathrm{MmNa}$ administered i.v.) $(p<0.001$, Table 1).

Table 1. The average concentrations of $\mathrm{MmNa}$ in the synovial fluid of inflamed joints of pigs following intravenous application and iontophoresis

\begin{tabular}{|c|c|c|c|c|}
\hline \multirow{3}{*}{ Drug tested } & \multicolumn{2}{|c|}{ Means of application and group } & \multirow{2}{*}{ Probability } & \multirow{2}{*}{ Significance } \\
\hline & i.v. (group A) & IPh (group B) & & \\
\hline & $\mathrm{X} \pm \mathrm{SD}$ & $\mathrm{X} \pm \mathrm{SD}$ & t-test & \multirow{2}{*}{$\mathrm{p}<0.001$} \\
\hline $\mathrm{MmNa}(\mu \mathrm{g} / \mathrm{g})$ & $9.81 \pm 1.56$ & $170.66 \pm 2.07$ & 19.438 & \\
\hline
\end{tabular}

The concentration of $\mathrm{MmNa}$ in the synovial fluid of inflamed joints in pigs was 17 fold higher when the drug was applied by iontophoretic means then it was after i.v. administration.

The difference between the average concentrations of $\mathrm{MmNa}$ in the hyaline cartilage of the inflamed joints following the two routes of administration (intravenous and iontophoretic) was similar to the aforementioned difference in the concentrations in the synovial fluid. Thus, the average concentration of $\mathrm{MmNa}$ in the hyaline cartilage obtained after iontophoretic application (group B) was significantly higher $(\mathrm{p}<0.001)$ i.e. approximately 43 times higher than the one following i.v. administration (group A) (Table 2).

Table 2. The average concentrations of $\mathrm{MmNa}$ in the hyaline cartilage of inflamed joints of pigs following intravenous application and iontophoresis

\begin{tabular}{|c|c|c|c|c|}
\hline \multirow{3}{*}{ Drug tested } & \multicolumn{2}{|c|}{ Means of application and group } & \multirow{2}{*}{ Probability } & \multirow{2}{*}{ Significance } \\
\hline & i.v. (group A) & IPh (group B) & & \\
\hline & $\mathrm{X} \pm \mathrm{SD}$ & $\mathrm{X} \pm \mathrm{SD}$ & t-test & \multirow{2}{*}{$\mathrm{p}<0.001$} \\
\hline $\mathrm{MmNa}(\mu \mathrm{g} / \mathrm{g})$ & $2.29 \pm 1.16$ & $98.36 \pm 21.58$ & 11.979 & \\
\hline
\end{tabular}

The difference between the average concentrations of $\mathrm{MmNa}$ in the synovial fluid and in the hyaline cartilage following IPh application was also subjected to statistical analysis. Predictably, it was confirmed that the concentration of this NSAID was significantly higher $(p<0.001)$ in the synovial fluid than in the hyaline cartilage (Table 3).

Table 3. The average concentrations of $\mathrm{MmNa}$ in the synovial fluid and hyaline cartilage of inflamed joints of pigs following electrophoretic application

\begin{tabular}{|c|c|c|c|c|}
\hline \multirow{2}{*}{ Drug tested } & Synovial fluid & $\begin{array}{c}\text { Hyaline carti- } \\
\text { lage }\end{array}$ & \multirow{2}{*}{ Probability } & Significance \\
\cline { 2 - 4 } & $\mathrm{X} \pm \mathrm{SD}$ & $\mathrm{X} \pm \mathrm{SD}$ & t-test & \multirow{2}{*}{$\mathrm{p}<0.001$} \\
\hline \hline $\mathrm{MmNa}(\mathrm{g}) / \mathrm{g}$ & $170.66 \pm 22.07$ & $98.36 \pm 21.58$ & 5.892 & \\
\hline
\end{tabular}


Furthermore, in the pigs which were administered MmNa by IPh (group B) the alterations in concentrations of $\mathrm{MmNa}$ in the synovial fluid were measured and their dependence on the time elapsed from the end of iontophoresis was analysed. Samples of synovial fluid were taken 3, 6, 9, 12 and 15 minutes after the process of iontophoresis ceased.

Regression analysis revealed the linear increase of $\mathrm{MmNa}$ concentrations through time (Figure 1). The increase in the concentration of NSAID was extremely steep, the correlation with time elapsed very high and the distribution of the concentrations of $\mathrm{MmNa}$ in each pig regular. In other words, the concentrations of $\mathrm{MmNa}$ rocketed steadily after iontophoretic application $(p<0.005)$, thus reaching very high values.

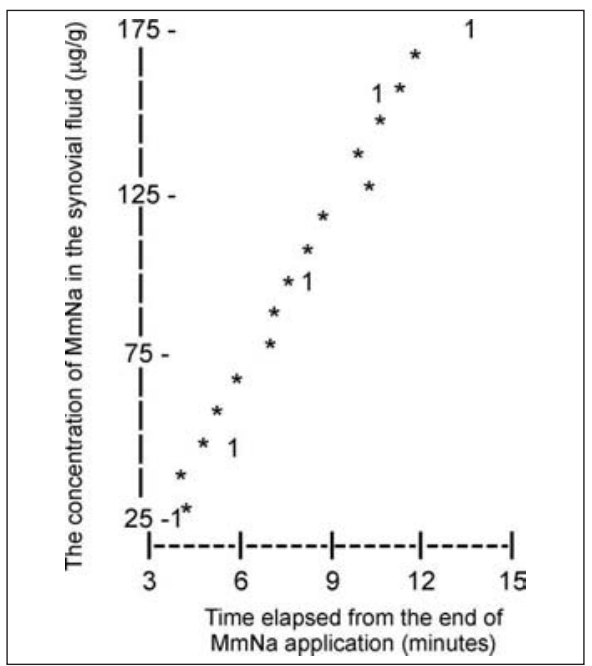

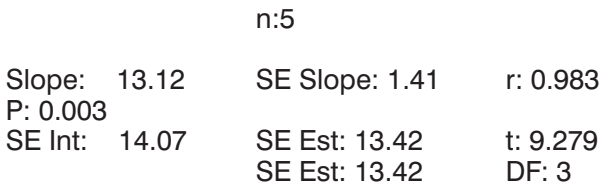

Figure 1. Concentration of $\mathrm{MmNa}$ in the synovial fluid after IPh application

\section{DISCUSSION}

In the present work the concentrations of $\mathrm{MmNa}$ in the synovial fluid and hyaline cartilage in inflamed joints of pigs were recorded. $\mathrm{MmNa}$ is a well known analgesic and antipyretic substance which has been in use in medicine since 1922 (Fendrich, 2000). Despite of its distinctive beneficial effects on pain relief and its antispasmodic action (Fendrich, 2000), there are certain disadvantages to its application, such as gastrointestinal irritability, and agranulocytosis (Ibanez et al., 2005). Agranulocytosis is thought to be of allergic origin, being the result of hypersensitivity due to the synthesis of antigens against this drug and had been underestimated until recent research (Hedenmalm and Spigset, 2002).

In the 1980s Offerhaus (Offerhaus, 1987) suggested that limiting the concern about risks of metamizol therapy to agranulocytosis inavoidably leads to an underestimation of the dangers of the drug. Further on, other serious immune reactions to dipyrone were reported, such as anaphylaxis, asthma, serum sickness, hypersensitivity vasculitis, alveolitis, pneumonitis, hepatitis, or 
haemolytic-uraemic syndrome, all of them occured about four times more often than agranulocytosis.

The comparison of average concentrations of $\mathrm{MmNa}$ in the synovial fluid and hyaline cartilage of inflamed knee and elbow joints in pigs after two different means of application revealed as follows: in the synovial fluid the average concentration of $\mathrm{MmNa}$ reached $170.66 \pm 2.07 \mu \mathrm{g} / \mathrm{g}$ when the drug was applied by iontophoresis and only $9.81 \pm 1.56 \mu \mathrm{g} / \mathrm{g}$ when applied i.v. The difference in concentrations was statistically significant, i.e. 17 fold higher concentrations were achieved when the drug was applied locally via iontophoresis.

The average concentration of $\mathrm{MmNa}$ in the hyaline cartilage following local administration was $98.36 \pm 21.58 \mu \mathrm{g} / \mathrm{g}$ in comparison with only $2.29 \pm 1.16 \mu \mathrm{g} / \mathrm{g}$ after i.v. application of $\mathrm{MmNa}$ in the same dose. Both in the synovial fluid and hyaline cartilage, the concentrations of NSAID were significantly higher after iontophoretic application in comparison with intravenous application. Predictably, the concentration of $\mathrm{MmNa}$ was significantly higher in the synovial fluid than in the hyaline cartilage of the pigs treated by iontophoresis $(170.66 \pm 22.07 \mu \mathrm{g} / \mathrm{g}$ vs. 98.36 $\pm 21.58 \mu \mathrm{g} / \mathrm{g})$.

Since cartilage does not possess blood or lymph vessels, perfusion is only possible from the synovial fluid and blood vessels of the subchondral bone. Therefore, the concentration of $\mathrm{MmNa}$ in the cartilage will continuously increase resulting in the higher concentrations in the synovial fluid due to osmosis, even after IPh or intravenous application of $\mathrm{MmNa}$ ceased. In our research the regression analysis of the concentrations of $\mathrm{MmNa}$ in the synovial fluid revealed linear increase in the concentrations of this NSAID proportional to the time elapsed after the iontophoresis. The increase in the concentration of the NSAID was extremely steep and the distribution of the concentrations of $\mathrm{MmNa}$ regular.

lontophoresis has certainly evolved in an attractive method for enhanced drug delivery especially for local anaesthesia prior to minor surgeries (Greenbaum, 2001) and topical anaesthesia which leads to acute and chronic pain relief (Zaciewski et al., 2007). In addition, it has been used successfully in rehabilitation medicine (Banga, 1998). Certain NSAIDs have been applied by iontophoretic means, diclofenac sodium, for example (Sanchez et al., 2002). Iontophoresis represents a meaningful way of local topical application of drugs avoiding systemic absorbtion and adverse effects.

lontophoresis is a painless, non-invasive mean of application of drugs which can be delivered even to parts of the body being difficult do approach, such as tarsal joints or tissues surrounding the hooves. Furthermore, infections are virtually impossible, high concentrations of $\mathrm{MmNa}$ are achievable locally while the concentrations in the systemic circulation are minimal, resulting in slight chances of adverse reactions.

Iontophoretic application of $\mathrm{MmNa}$ is advisable particularly in cases of arthritis of different or unknown etiology, which affects two or more joints. IPh can be performed on humans and animals, safely and harmlessly provided the thresholds are known for affected species. Even horses tollerate the use of current for drug transfer. 
Last, but not least, in comparison with enteral and parenteral administration IPh produces remarkable therapeutic effects with smaller quantities of drugs, which is an additional economic benefit in veterinary and human medicine.

Having in mind all the afore mentioned, we can certainly recommend the topical, iontophoretic use of $\mathrm{MmNa}$ in the therapy of disorders of the musculoskeletal system and in rehabilitation medicine in animals and humans.

\section{ACKNOWLEDGEMENTS:}

This research was supported by the Ministry of Science of Serbia, Project Grant No. 20142.

Address for correspondence:

Dr Milanka Jezdimirovic, Professor

Faculty of Veterinary Medicine

University of Belgrade

Bulevar oslobodjenja 18

11000 Beograd, Serbia

E-mail: milanka@vet.bg.ac.rs

\section{REFERENCES}

1. Asmardi G, Jamali $F, 1985$, Pharmacokinetics of dipyrone in man: role of the administration route, Eur J Drug Metab Ph, 10, 121-5.

2. Banga AK, Panus PC, 1998, Clinical applications of iontophoretic devices in rehabilitation medicine, Crit Rev in Rehab Med, 10, 147-79.

3. Baskurt F, Özcan A, Algun C, 2003, Comparison of effects of phonophoresis and iontophoresis of naproxen in the treatment of lateral epicondylitis, Clin Rehab, 17, 96-100.

4. Berkow R, 1987, Musculosceletal and connective tissue disorders, In Berkow R (ed): The Merck Manual, New York, Merck Manual, Merck Sharp \& Dohme Research Laboratories, 1304-10.

5. Bigal ME, Bordini CA, Speciali JG, 2001, Intravenous metamizol (Dipyrone) in acute migraine treatment and in episodic tension-type headache - a placebo-controlled study, Cephalalgia, 21, 90-5.

6. Boothe DM, 2001, Drugs affecting gastrointestinal function, In: Adams HR, editor, Veterinary pharmacology and therapeutics, 8th ed, lowa State University Press, 1053.

7. Candek-Potokar M, Zlender B, Bonneau M, 2002, Effects of breed and slaughter weight on longissimus muscle biochemical traits and sensory quality in pigs, Annal Zootech, 47, 17-38.

8. Ciccone CD, 1995, Iontophoresis, In: Robinson AJ, Snyder-Mackler L, Clinical electrophysiology: electrotherapy and electrophysiologic testing, 2nd Ed., Williams \& Wilkins, Baltimore, 490.

9. EMEA Metamizole Summary Report (2), 2003, www.emea.europa.eu/pdfs/vet/mrls/087803en.pdf. Viewed: 29 Oct, 2008.

10. Fendrich Z, 2000, Metamizol - a new effective analgesic with a long history. Overview of its pharmacology and clinical use (Article in Czech), Cas Lek Ces, 139, 14, 440-4.

11. Greenbaum SS, 2001, Iontophoresis as a tool for anesthesia in dermatologic surgery: An overview : Anesthesia, Dermatol Surg, 27, 12, 1027-30.

12. Grundmann U, Wörnle C, Biedler A, Kreuer S, Wrobel M, Wilhelm W, 2006, The Efficacy of the NonOpioid Analgesics Parecoxib, Paracetamol and Metamizole for Postoperative Pain Relief After Lumbar Microdiscectomy, Anesth Analg, 103, 217-22.

13. Hedenmalm K, Spigset O, 2002, Agranulocytosis and other blood dyscrasias associated with dipyrone (metamizole), Eur J Clin Pharmacol, 58, 4, 265-74.

14. Ibanez L, Vidal X, Ballarin E, Laporte J, 2005, Agranulocytosis associated with dipyrone (metamizol), EurJ Clin Pharmacol, 60, 11, 821-9. 
15. Laird JMA, Roza C, Olivar T, 2004, Antinociceptive activity of metamizol in rats with experimental ureteric calculosis: Central and peripheral components, Inflammation Research, 47, 10, 38995.

16. Lees P, Landoni MF, Giraudel J, Toutain PL, 2004, Pharmacodynamics and pharmacokinetics of nonsteroidal anti-inflammatory drugs in species of veterinary interest, J Vet Pharmacol Ther, 27, 479-90.

17. Maitland GD, 1986, Le genou, In: Corriggan B, Maitland GD, (eds): Medicine ortopedique pratique, Masson, Paris, 166-79.

18. Offerhaus L, 1987, Metamizol: een honderdjarige treurnis. Ned Tijdschr Genees, 131, 479-81.

19. Phipps JB, Padmanabhn RV, Lattin, GA, 1989, lontophoretic delivery of model inorganic and drug ions, J Pharm Sci, 78, 365-9.

20. Sanchez S, Alarcon de la Lastra C, Ortiz P, Motilva V and Martin MJ, 2002, Gastrointestinal Tolerability of Metamizole, Acetaminophen and Diclofenac in Subchronic Treatment in Rats, Digest Dis Sci, 47, 2791-8.

21. Tashiro Y, Kato Y, Hayakama E, Ito $K, 2000$, lontophoretic transdermal delivery of ketoprofen: effect of iontophoresis on drug transfer from skin to cutaneous blood, Biol Pharm Bull, 23, 1486-90.

22. Tashiro Y, Shichibe S, Kato Y, Hayakawa E, Itoh K, 2001, Effect of lipophilicity on in vivo iontophoretic delivery. I. NSAIDs, Biol Pharm Bull, 24, 278-83.

23. The European Convention for the Protection of Vertebrate Animals used for Experimental and Other Scientific Purposes, http://conventions.coe.int/treaty/en/Treaties/Html/123.htm, Viewed: 5 Nov, 2008

24. Underwood M, Ashby D, Carnes D, Castelnuovo E, Cross P, Harding G, Hennessy E, Letley L, Martin J, Mt-Isa S, Parsons S, Spencer A, Vickers M, Whyte K, 2008, Topical or oral ibuprofen for chronic knee pain in older people. The TOIB study, Health Technol Assess, 12, 22.

25. Vangsness Ct, Mitchell W, Nimni M, 1997, Collagen shortening: an experimental approach with heat, Clin Ortop, 337, 267-71.

26. Weissmann G, 1991, The actions of NSAIDs, Hosp Pract, 15, 60-76.

27. Zaciewski T, Brickman K, Wellock AR, Adams DZ, 2007, The use of iontophoresis in the pain management of soft tissue injuries in the emergency department: A pilot study, J Emerg Med, MEMC IV Abstracts, 330-1.

\title{
ODREĐIVANJE KONCENTRACIJA METAMIZOL-NATRIJUMA U INFLAMIRANIM ZGLOBOVIMA SVINJA POSLE INTRAVENSKE I ELEKTROFORETSKE APLIKACIJE
}

\author{
ĐURĐEVIĆ S, JEZDIMIROVIĆ MILANKA, ALEKSIĆ NEVENKA, BRANKOVIĆ NATAŠA, \\ PRŽULJ D i CICOVIĆ B
}

\section{SADRŽAJ}

U sinovijalnoj tečnosti i hijalinoj hrskavici inflamiranog kolenog i lakatnog zgloba svinja određivane su koncentracije metamizol-natrijuma ( $\mathrm{MmNa}$ ) aplikovanog i.v. i putem elektroforeze. Arteficijelno zapaljenje kolena i lakta prasadi izazvano je terpentinskim uljem. Metamizol-natrijum je primenjen u dozi od $2.5 \mathrm{~g} \mathrm{u}$ prvoj grupi prasadi intravenski, a u drugoj putem elektroforeze u kontalateralni koleni i lakatni zglob. Četiri sata posle aplikacije MmNa urađena je biopsija tretiranih zglobova. Prosečna koncentracija MmNa u sinovijalnoj tečnosti inflamiranih

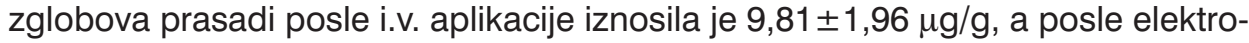


foreze bila je $170,66 \pm 2,07 \mu \mathrm{g} / \mathrm{g}$ tkiva, odnosno oko 17 puta viša. Izmerena prosečna koncentracija MmNa u hijalinoj hrskavici iznosila je 2,29 $\pm 1,16 \mu \mathrm{g} / \mathrm{g}$ posle i.v. aplikacije i 98,36 $\pm 21,58 \mu \mathrm{g} / \mathrm{g}$ posle aplikacije elektroforezom, odnosno oko 43 puta više. Zaključujeno je da MmNa primenjen elektroforezom postiže statistički veoma značajno više prosečne koncentracije u inflamiranim zglobovima u odnosu na i.v. aplikaciju. Primena MmNa elektroforezom ima značajnu prednost nad i.v. aplikacijom ovog leka ne samo zbog postizanja značajno viših koncentracija u inflamiranim zglobovima, već i zbog izostajanja sistemskih neželjenih reakcija. 